\title{
An integrated system of biological and catalytic oxidation for the removal of $o$-xylene from exhaust
}

\author{
Lin Li, Changbin Zhang, Hong He, Junxin Liu * \\ Research Center for Eco-Environmental Sciences, Chinese Academy of Sciences, P.O. Box 2871, Beijing 100085, PR China
}

Available online 17 July 2007

\begin{abstract}
Biofiltration is an efficient technology for treatment of gaseous waste. Its disadvantages, however, include large volume of bioreactor and slow adaptation to fluctuating concentrations in waste gas. Catalytic oxidation offers a high destructive efficiency at relatively low operating temperature and small unit. A bench scale system integrated with a biofilter and a catalytic oxidation unit for the treatment of gases containing $o$-xylene was investigated in this study. The catalytic oxidation unit was packed with $\mathrm{Cu} / \mathrm{Al}_{2} \mathrm{O}_{3}$ catalyst. The results showed that $90 \%$ of $o$-xylene could be removed in the biofilter at the load below $38.2 \mathrm{~g} \mathrm{~m}^{-3} \mathrm{~h}^{-1}$. High $o$-xylene concentration in inlet gas resulted in an overload of the biofilter. Using the $\mathrm{Cu} / \mathrm{Al}_{2} \mathrm{O}_{3}$ catalytic oxidation unit, the concentration of $o$-xylene could be reduced evidently. The combination of the chemical and microbial processes not only led to a high and stable efficiency of $o$-xylene conversion, but also improved capacity resisting the shock loads. The $\mathrm{Cu} / \mathrm{Al}_{2} \mathrm{O}_{3}$ was studied for $o$-xylene oxidation in temperature range of $90-320^{\circ} \mathrm{C}$. The $o$-xylene conversion was improved correspondingly with the increasing of oxidation temperature. The reaction mechanism of $o$-xylene oxidation on $\mathrm{Cu} / \mathrm{Al}_{2} \mathrm{O}_{3}$ was also investigated using diffuse reflectance infrared Fourier transform spectroscopy (DRIFTS).
\end{abstract}

(C) 2007 Elsevier B.V. All rights reserved.

Keywords: Integrated system; Bioreactor; Catalytic oxidation; Exhaust treatment; $o$-Xylene

\section{Introduction}

Volatile organic compounds (VOCs) can be produced from a variety of industrial and commercial processes, including printing, metal decorating, paint drying, manufacturing of organic compounds and polymers. Legislation has already been introduced to reduce their emissions due to their potential threat to environment and human health. Compared with conventional physical-chemical technologies, biological technologies such as biofilters, bioscrubbers and biotrickling filters are cost-effective alternatives to treat VOCs contaminated air streams, particularly useful in treatment of high volume/low concentration emissions [1]. Various VOCs, e.g. styrene [2-4], BTEX [5], pentane and toluene [6], benzene [7], toluene and styrene [8,9], $\alpha$-pinene [10], chlorinated compounds and $p$-xylene [11], could be degraded effectively by biological methods. However, biological process

\footnotetext{
* Corresponding author at: Research Center for Eco-Environmental Sciences, Chinese Academy of Sciences, P.O. Box 2871, Beijing 100085, PR China.

E-mail addresses: leel@rcees.ac.cn (L. Li), jxliu@rcees.ac.cn (J. Liu).
}

relies solely on the capability of specific microbial species to oxidize the targeted organic pollutants. Biodegradation of organic contaminants to mineral products occurs in steps, producing intermediate compounds. An overloaded biofilter may result in acetic acid accumulation and high effluent concentration of untreated gas [12]. For these reasons, bioreactors are sensitive to surges in VOCs loadings, and therefore biological methods is not suitable for treating waste gases containing relatively high concentrations of volatile compounds [13]. Moreover, biological process requires larger land area than other treatment systems, which limits the feasibility of this technology due to pricey land acquisition.

Incineration, condensation, scrubbing, adsorption or catalytic oxidation can remove VOCs in exhaust gases. Incineration, the most often used method, destroys these compounds by burning them at temperature higher than $1000^{\circ} \mathrm{C}$. The high temperature results in the formation of undesirable by-products such as nitrogen oxides, dibenzofurans, dioxins, etc. [14]. Catalytic oxidation offers a high destructive efficiency at a relatively low operating temperature and small unit size. The catalytic oxidation of aromatic VOCs has been investigated 
over various catalysts [15-18]. Compared with noble metals (platinum, palladium), $\mathrm{Cu}$-supported catalysts are economically favorable. The oxidation of various hydrocarbons, e.g. benzene [19], toluene, benzene and xylene [20] and other organic materials [21], has already been investigated with similar catalysts. However, these chemical processes are costly and energy intensive.

The selection of treatment methods depends on the nature of the compounds to be treated, the concentration, flow rate and mode of emission of the gaseous waste stream. Despite the difference in emission standards of different countries, the general trend leans towards more strict regulation of air emission. This requires combinations of various technologies to meet the strict standards.

In this study, an integrated reactor, consisting of a biofiltration unit and a catalytic oxidation unit, was used to treat gaseous waste containing $o$-xylene. The objectives were to further improve the efficiency of VOCs removal by integrating biological and catalytic oxidation processes, to minimize the volume of biofilter, and to make the biofilter sound in resisting the shocking inlet load.

\section{Materials and methods}

\subsection{Integrated system of biological and catalytic oxidation}

The experiments were continuously conducted using the bench-scale integrated reactor system (Fig. 1). This system includes a biofilter, a catalytic oxidation unit and a desiccation unit. As gases flow through the biofilter, biodegradable compounds are absorbed and subsequently biodegraded by microorganisms attached growth on packing material. The gases then flow into the desiccation tube. After being dried by the desiccant, the gases with residual contaminants enter the catalytic oxidation unit packed with $\mathrm{Cu} / \mathrm{Al}_{2} \mathrm{O}_{3}$ catalyst. The catalyst in the reactor tube activates oxygen in the gases at relative low temperature. Therefore, these compounds were adsorbed and oxidized into carbon dioxide and water by the activated oxygen.
Biological degradation of VOCs was carried out in the biofiltration unit, which is a single stage Plexiglas column with a $100 \mathrm{~cm}$ in length and $10 \mathrm{~cm}$ in inner diameter. The effective volume of the biofiltration unit was $5 \mathrm{~L}$. It was packed with polyurethane foam cubes for attached growth of microorganisms. The sampling ports were located at both inlet and outlet of the biofiltration unit in correspondence to compound concentrations prior and after the treatment.

A glass tube reactor of $2 \mathrm{~cm}$ in diameter with a working volume of $0.033 \mathrm{~L}$ was used as a catalytic oxidation unit. The catalyst was supported in a small plug of glass wool. Sampling ports were provided at the bottom and the top of the catalytic oxidation unit for the determination of compound concentrations in untreated and treated gases. A thermocouple was inserted along the outside wall of the reactor tube to measure the temperature of the tube. As the moisture in the exhaust from the biofilter would be harmful to the catalyst, desiccation unit packed with silicon gel was to dry up the gases before they enter the catalytic oxidation unit.

\subsection{Experimental compounds and catalysts}

$o$-Xylene, one of the priority environmental toxic pollutants quoted by the US Environmental Protection Agency (EPA) [9], was chosen as experimental compound in this study.

$\mathrm{Cu}(10 \mathrm{wt} . \%) / \mathrm{Al}_{2} \mathrm{O}_{3}$ catalyst was prepared by an impregnation method as follows: $\mathrm{Al}_{2} \mathrm{O}_{3}$ powder was added into an appropriate amount of copper nitrate aqueous solution under stirring. The sample was dried at $120^{\circ} \mathrm{C}$ for $12 \mathrm{~h}$ and calcined at $600{ }^{\circ} \mathrm{C}$ for $3 \mathrm{~h}$ in air [22].

\subsection{Experimental conditions}

The synthetic gaseous waste stream was generated as follows. Two air compressors supplied the airflow. A small stream of air was bubbled through a vessel containing pure $o$-xylene solvent and then mixed with a large gas stream. The desired concentration of experimental compounds in the influent

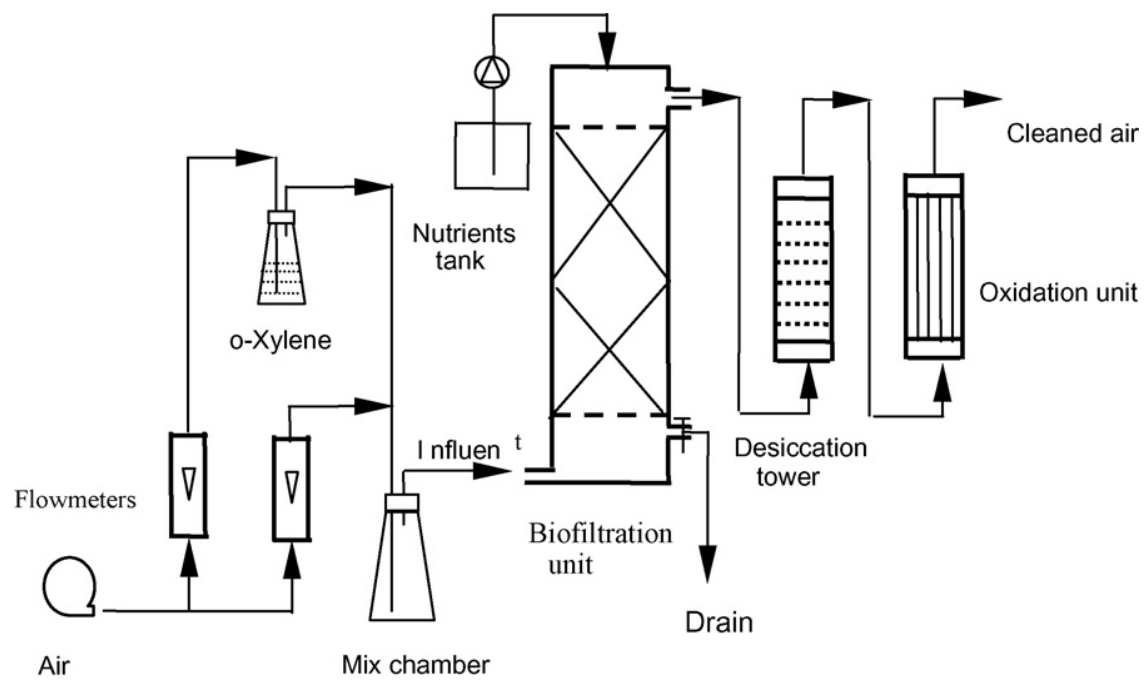

Fig. 1. Schematic diagram of the integrated reactor system. 
air stream was maintained by adjusting the rates of the two airflows.

The biodegradation was carried out in a laboratory, with seasonal temperature change from 20 to $33{ }^{\circ} \mathrm{C}$. The $\mathrm{pH}$ value in the biofiltration unit was measured regularly to maintain the $\mathrm{pH}$ in the range of 5-6. The growth of microorganisms in the biofiltration unit was provided by the nutrients available in the packing material. Thus, the packing material was soaked in the nutrient solution ( $\mathrm{pH}$ 5.5-6.0) before packing, and the nutrients solution was added into the biofiltration unit once every 2 weeks during the running period. Redundant nutrient solution was drained from the bottom of the unit.

The catalytic oxidation of $o$-xylene over $\mathrm{Cu} / \mathrm{Al}_{2} \mathrm{O}_{3}$ was carried out in the temperature range of $90-320{ }^{\circ} \mathrm{C}$. The space velocity for the reaction was at $11000 \mathrm{~h}^{-1}$.

\subsection{Analytical methods}

The performance of the integrated system was monitored by measuring the changes of $o$-xylene and $\mathrm{CO}_{2}$ concentrations in gases at the inlet and the outlet, as well as the $\mathrm{pH}$, relative humidity $(\mathrm{RH})$ and temperature. The $\mathrm{pH}$ value was measured by a $\mathrm{pH}$ meter (PH-3C, Shanghai). The Dewpoint Thermohygrometer (WD-35612, OAKTON, Germany) was used to measure $\mathrm{RH}$ and temperature. The concentrations of $\mathrm{CO}_{2}$ in the air stream at the inlet and the outlet were analyzed by a $\mathrm{CO}_{2}$ analyzer (VIA-510 HORIBA, Japan). $o$-Xylene was analyzed by directly injecting air samples into a gas chromatography (Agilent $6890 \mathrm{~N}, \mathrm{USA}$ ) with a flame ionization detector (FID). A HP-5 column of $\varnothing 0.32 \mathrm{~mm} \times 30 \mathrm{~m}$ was used at $180{ }^{\circ} \mathrm{C}$ with nitrogen carrier gas at a pressure of 25 psi. Retention time for $o$ xylene was about $1.49 \mathrm{~min}$.

Diffuse reflectance infrared Fourier transform spectroscopy (DRIFTS) were recorded in a NEXUS 670-FTIR (Nicolet) ( $4 \mathrm{~cm}^{-1}$ resolution) equipped with a smart collector and a liquid $\mathrm{N}_{2}$ cooled MCT detector. The sample was placed in a ceramic crucible. Before the experiment, the catalyst was firstly pre- treated in a flow of $30 \% \mathrm{O}_{2}$ and $70 \% \mathrm{~N}_{2}$ for $60 \mathrm{~min}$ at $500{ }^{\circ} \mathrm{C}$, and then cooled down to a suitable temperature in a flow of $\mathrm{O}_{2}$ and $\mathrm{N}_{2}$ for $15 \mathrm{~min}$. A spectrum of the catalyst in the flow of $\mathrm{O}_{2}$ and $\mathrm{N}_{2}$ served as the background was recorded. A flow of feed gas mixture controlled by mass flow meters was fed at a flow rate of $100 \mathrm{ml} \mathrm{min}{ }^{-1}$. All spectra were recorded under real reaction conditions with a resolution of $4 \mathrm{~cm}^{-1}$ and accumulating 100 scans.

Temperature programmed oxidation (TPO) test was performed in a quartz reactor at a flow rate of $30 \mathrm{~cm}^{3} \mathrm{~min}^{-1}$ $10 \% \mathrm{O}_{2} / \mathrm{He}$ with a constant heating rate of $30{ }^{\circ} \mathrm{C} \mathrm{min}^{-1}$. The TPO pattern was recorded by a Hiden HPR20 TPD apparatus within the temperature range of $25-800{ }^{\circ} \mathrm{C}$.

\section{Results and discussion}

\subsection{Continuous conversion of o-xylene in the integrated system}

The capacity of the integrated system for $o$-xylene removal was examined for more than 6 months by changing the concentrations of $o$-xylene at the inlet. The range of $o$-xylene concentrations in inlet gases was $400-2500 \mathrm{mg} \mathrm{m}^{-3}$. The gas flow rate in biofiltration unit was $0.35 \mathrm{~m}^{3} \mathrm{~h}^{-1}$. As the working volume of catalytic oxidation unit was $0.033 \mathrm{~L}$, the corresponding space velocity for the catalytic oxidation was at $11000 \mathrm{~h}^{-1}$.

In this study, the biodegradation of $o$-xylene in biofiltration unit was carried out continuously, and the catalytic oxidation unit was operated intermittently. The catalytic oxidation unit was used only when the biofiltration unit was in adaptation period or underwent fluctuating loads. Fig. 2 demonstrates the changes of $o$-xylene concentrations in inlet gas $\left(C_{\text {in }}\right)$, effluent gas of the biofiltration unit $\left(C_{\text {out(B) }}\right)$ and catalytic oxidation unit $\left(C_{\text {out }(\mathrm{O})}\right)$. The removal efficiencies of biofiltration unit $\left(R_{\mathrm{B}}\right)$ was $\triangle$ and total removal efficiencies of integrated reactor system $\left(R_{\mathrm{T}}\right)$ was $\diamond$ (Fig. 2).

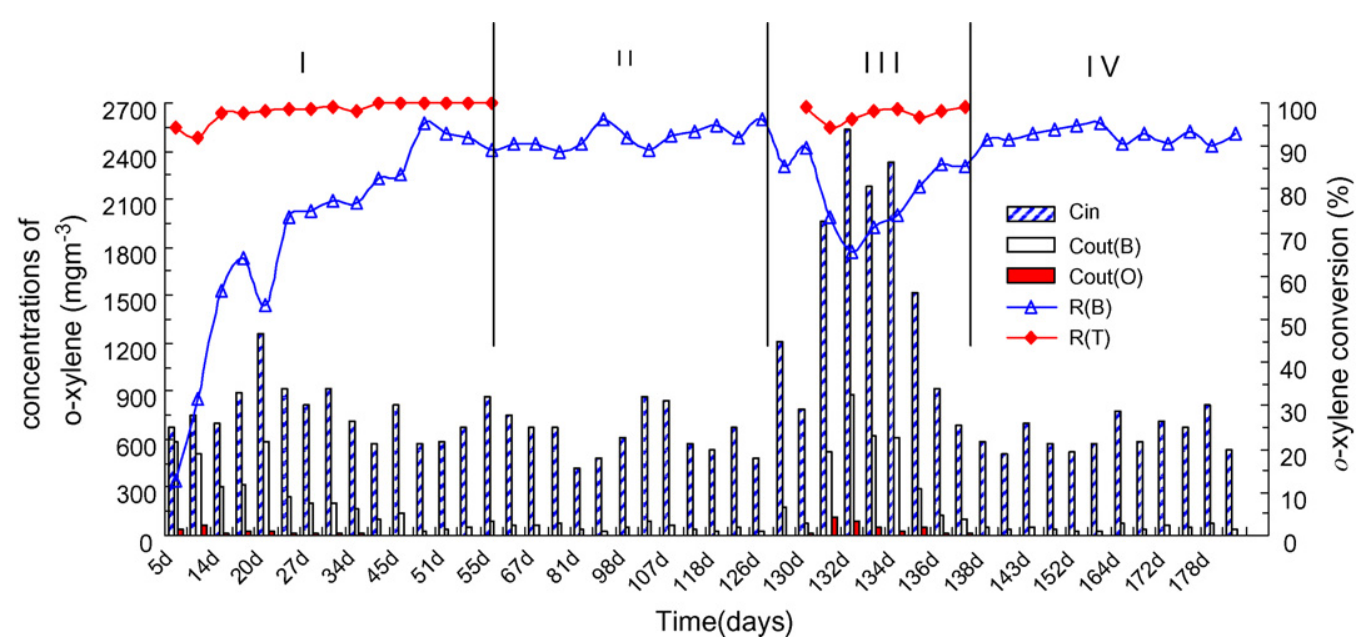

Fig. 2. Concentration and conversion of $o$-xylene in integrated system. Reaction conditions: $o$-xylene $400-2500 \mathrm{mg} \mathrm{m}^{-3}$ with air balance; temperature: ambient temperature for biodegradation unit and $320^{\circ} \mathrm{C}$ for catalytic oxidation unit; total flow: $0.35 \mathrm{~m}^{3} \mathrm{~h}^{-1}$; GHSV: $11000 \mathrm{~h}^{-1}$. ( $C_{\mathrm{in}}$ : inlet concentrations of $o$-xylene; $C_{\mathrm{out}}$ (B): effluent concentrations of $o$-xylene from the biofiltration unit; $C_{\mathrm{out}(\mathrm{O})}$ : effluent concentrations of $o$-xylene from catalytic oxidation unit; $\left(R_{\mathrm{B}}\right)$ : the removal efficiencies of biofiltration unit; $R_{\mathrm{T}}$ : total removal efficiencies of integrated reactor system). 
The continuous conversion experiments (over 6 months) were divided into four stages according to the operation state of the biofiltration unit. Stage I (1st day to 55th day) was the period of acclimation. Stage II (from the 56th day to 129th day) and Stage IV (from the 131st day to 182nd day) were both in the steady state period of the biofiltration unit. From the 130th day to 138th day was Stage III, presented by the occurrences of overloads in the biofiltration unit.

Fig. 2 shows clearly that the outlet concentrations of $o$ xylene changed with inlet concentrations. During Stage I, the concentrations of $o$-xylene in gases from biofiltration unit often exceeded $200 \mathrm{mg} \mathrm{m}^{-3}$, and were much higher than those from the catalytic oxidation unit. The removal efficiency of the biofiltration unit was only $15 \%$ at the stage. The amounts of microorganisms attached growth on the filter were not enough to effectively degrade $o$-xylene when the biofiltration unit was in adaptation state. Therefore, the catalytic oxidation unit was necessary to further treat the gas from the biofiltration unit so as to reduce the concentration of $o$-xylene below the emission standards. Results indicated that $o$-xylene effluent concentration from the catalytic oxidation unit could be maintained less than $100 \mathrm{mg} \mathrm{m}^{-3}$, and then the total removal efficiency of the integrated system reached $98 \%$.

The removal efficiency of the biofiltration unit was then increased gradually from 15 to $90 \%$, and remained at that level became stable within 55 days. The biofiltration unit was considered in steady state when the average removal efficiency in the biofiltration unit was stable at over $90 \%$. In the steady state, the concentration of $o$-xylene in effluent gases was below $100 \mathrm{mg} \mathrm{m}^{-3}$ while inlet $o$-xylene concentration was less than $800 \mathrm{mg} \mathrm{m}^{-3}$. To save cost and energy, the system was operated without the catalytic oxidation unit. Indeed, during the periods of Stage II and Stage IV, the biofiltration unit itself had reached the maximum $o$-xylene removal capacity of $80 \mathrm{~g} \mathrm{~m}^{-3} \mathrm{~h}^{-1}$ with an average of $35.1 \mathrm{~g} \mathrm{~m}^{-3} \mathrm{~h}^{-1}$.

When the inlet concentration of $o$-xylene was suddenly increased from 800 to $2000 \mathrm{mg} \mathrm{m}^{-3}$ in Stage III, the concentration of $o$-xylene from the biofiltration unit increased evidently and the average removal efficiency of biofiltration unit decreased from 90 to $70 \%$, indicating that the overloading in the biofiltration unit had overwhelmed the capacity. Logically, enlarging the volume of the biofiltration unit would be very effective in dealing with this problem, but it is probably not the best solution due to land area requirement and inconvenience in operation. In order to ensure the elimination efficiency, the catalytic oxidation unit was used in this Stage. Results in Fig. 2 revealed that the average concentration of $o$ xylene out from the catalytic oxidation unit was as low as $42 \mathrm{mg} \mathrm{m}^{-3}$, and the total $o$-xylene conversion efficiency was over $98 \%$ in the integrated system. Therefore, it is feasible to effectively remove $o$-xylene by using the catalytic reaction unit when the biofiltration unit encounters with shocking loads.

The combining biofiltration and catalytic oxidation system performance was significantly improved, especially during the acclimation period (e.g. Stage I) and in the cases when the contaminant loading became high (e.g. Stage III). Catalytic oxidation unit does not require any acclimation period and is capable of becoming operational rapidly. This is potentially valuable for the industrial application of the integrated system where the catalytic oxidation unit can be installed followed by the biofiltration unit, and can be operated only when required. This, in turn, would make the whole treatment more feasible economically.

\subsection{Elimination capacity of the integrated system}

The removal capacity of the biofiltration unit and the integrated system were presented in Fig. 3, where the elimination capacities of $o$-xylene were plotted versus the $o$ xylene load at different inlet concentrations. According to those results obtained from the biofiltration unit, a linear relationship was observed between the elimination capacity and the $o$ xylene when the $o$-xylene loading rate was less than $100 \mathrm{~g} \mathrm{~m}^{-3} \mathrm{~h}^{-1}$. Beyond this value, the elimination capacity increased slowly and reached to its maximum capacity of $80 \mathrm{~g} \mathrm{~m}^{-3} \mathrm{~h}^{-1}$. This threshold was obtained at an inlet load of $210.8 \mathrm{~g} \mathrm{~m}^{-3}$ and a flow rate of $0.35 \mathrm{~m}^{3} \mathrm{~h}^{-1}$. Such behavior of the elimination capacity indicated that a linear relationship between the removal rate and the inlet load occurred at low loading rates of the $o$-xylene when the pollutant was nearly completely removed. With further increase of the loading rate, the elimination rate was increased slowly and plateaued, indicating that the maximum elimination capacity of the biofiltration unit was achieved. When the inlet load was over $180 \mathrm{~g} \mathrm{~m}^{-3} \mathrm{~h}^{-1}$, the $o$-xylene elimination capacity fell down. However, the total elimination capacity was still increased linearly with the inlet loading rates, and the higher removal efficiency was obtained in the integrated system, which benefited from the catalytic oxidation.

The work volume of biofiltration unit used in this experiment was $5.0 \mathrm{~L}$. When the biofiltration was overloaded, its average elimination capacity was $57.3 \mathrm{~g} \mathrm{~m}^{-3} \mathrm{~h}^{-1}$ and its average removal efficiency dropped to $60 \%$. Using the catalytic oxidation unit, the total removal efficiency could be still kept a high conversion. In contrast, the volume of biofiltration unit

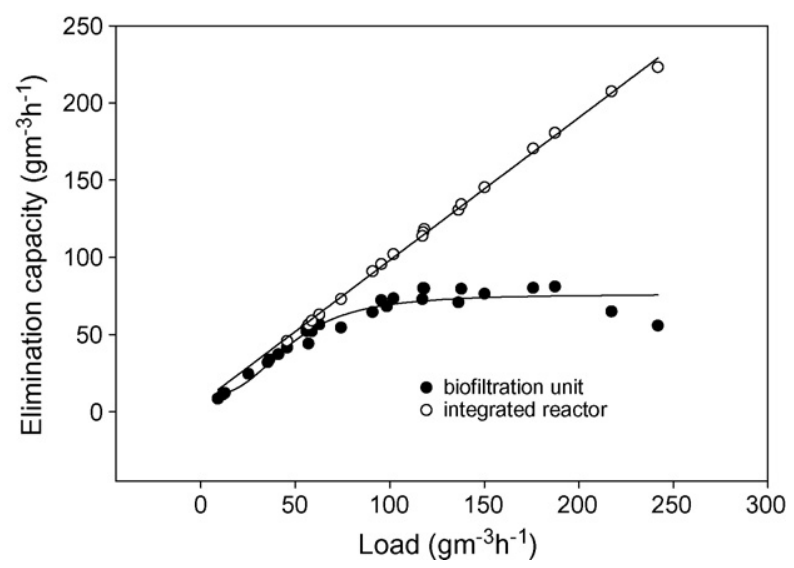

Fig. 3. Elimination capacity vs. $o$-xylene inlet load for various gas flow rates. Reaction conditions: $o$-xylene $400-2500 \mathrm{mg} \mathrm{m}^{-3}$ with air balance; temperature: ambient temperature for biodegradation unit and $320^{\circ} \mathrm{C}$ for catalytic oxidation unit; total flow: $0.35 \mathrm{~m}^{3} \mathrm{~h}^{-1}$; GHSV: $11000 \mathrm{~h}^{-1}$. 
Table 1

Effect of the temperature in the catalytic oxidation unit on $o$-xylene conversion $\left(C_{\mathrm{in}}\right.$ : inlet concentration)

\begin{tabular}{|c|c|c|c|}
\hline \multirow[t]{2}{*}{ Catalytic oxidation temperature $\left({ }^{\circ} \mathrm{C}\right)$} & \multicolumn{3}{|c|}{ Removal of $o$-xylene $(\%)$} \\
\hline & $C_{\mathrm{in}}=208.6\left(\mathrm{mg} \mathrm{m}^{-3}\right)$ & $C_{\mathrm{in}}=461.7\left(\mathrm{mg} \mathrm{m}^{-3}\right)$ & $C_{\mathrm{in}}=922.6\left(\mathrm{mg} \mathrm{m}^{-3}\right)$ \\
\hline 90 & 0 & 0 & - \\
\hline 135 & 7.1 & 0 & - \\
\hline 180 & 22 & 20 & - \\
\hline 245 & 38.9 & 35.5 & 35.5 \\
\hline 260 & 55.1 & 57.9 & 51.1 \\
\hline 280 & 84.6 & 80.5 & 70.5 \\
\hline 320 & 100 & 98 & 97.2 \\
\hline
\end{tabular}

would have to be $8.5 \mathrm{~L}$ to obtain the same removal efficiency without the catalytic oxidation unit. Therefore, the combination of biodegradation and catalytic oxidation not only improves the elimination capacity of contaminants, but also minimizes the volume of the biofiltration unit.

In addition, the component analysis was performed for the outlet gas of the biofiltration unit by the detection of GC-MS (Agilent 6890N/5973N, USA). No other carbon containing intermediates entered the oxidation unit except the $o$-xylene and $\mathrm{CO}_{2}$ (data not shown). In the following study, the influences of inlet concentrations and temperatures on the $o$-xylene conversion of catalytic oxidation unit were investigated.

\subsection{Influence factors on o-xylene conversion in the catalytic oxidation unit}

\subsubsection{Temperature}

The conversion of $o$-xylene over $\mathrm{Cu} / \mathrm{Al}_{2} \mathrm{O}_{3}$ catalyst was investigated at the temperatures ranging from 90 to $320^{\circ} \mathrm{C}$. The time for oxidation was $60 \mathrm{~min}$ and three inlet concentrations (208.6, 461.7 and $922.6 \mathrm{mg} \mathrm{m}^{-3}$ ) of $o$-xylene were studied. The results for $90{ }^{\circ} \mathrm{C}, 135^{\circ} \mathrm{C}, 180{ }^{\circ} \mathrm{C}, 245^{\circ} \mathrm{C}, 260{ }^{\circ} \mathrm{C}, 280{ }^{\circ} \mathrm{C}$ and $320^{\circ} \mathrm{C}$ are listed in Table 1 . It shows that no $o$-xylene conversion occurred below $90^{\circ} \mathrm{C}$. When temperature was below $180^{\circ} \mathrm{C}$, only a little $o$-xylene was removed even at low $o$ xylene inlet concentration. Increasing oxidation temperature improved $o$-xylene conversion efficiency over $\mathrm{Cu} / \mathrm{Al}_{2} \mathrm{O}_{3}$, and $100 \%$ of $o$-xylene conversion was obtained at $320{ }^{\circ} \mathrm{C}$. At the same inlet concentration of $o$-xylene, the higher the temperature was, the higher the removal efficiency could be obtained.

\subsubsection{Reaction time}

The performance of $\mathrm{Cu} / \mathrm{Al}_{2} \mathrm{O}_{3}$ in $o$-xylene conversion and selectivity of $\mathrm{CO}_{2}$ formation were also investigated. The inlet concentration of $o$-xylene was $461.6 \mathrm{mg} \mathrm{m}^{-3}$ and the space velocity for the reaction was $11000 \mathrm{~h}^{-1}$. The results for 245 , 280 and $320{ }^{\circ} \mathrm{C}$ are shown in Figs. 4 and 5. At $245^{\circ} \mathrm{C}$, the apparent removal of $o$-xylene was decreased sharply from 90 to $50 \%$ within several minutes, then gradually dropped to $30 \%$ after $30 \mathrm{~min}$. The similar behavior was observed at $280{ }^{\circ} \mathrm{C}$. This sharp decrease of $o$-xylene conversion is likely due to the adsorption of $o$-xylene over $\mathrm{Cu} / \mathrm{Al}_{2} \mathrm{O}_{3}$. One may also observed that the conversion of $o$-xylene slowly decreased with time after the incipient sharp decrease. The reason of deactivation will be discussed below. However, at a higher temperature of $320{ }^{\circ} \mathrm{C}$, the $o$-xylene conversion could reach $98 \%$ at $320{ }^{\circ} \mathrm{C}$ (Fig. 4).

The $\mathrm{CO}_{2}$ selectivity increased with time, and reached to a steady value of $70 \%$ and $90 \%$ after $30 \mathrm{~min}$ at $245^{\circ} \mathrm{C}$ and $280{ }^{\circ} \mathrm{C}$, respectively. At $320{ }^{\circ} \mathrm{C}, 100 \%$ selectivity to $\mathrm{CO}_{2}$ was obtained after more than $10 \mathrm{~min}$, and this complete conversion could be maintained for more than $1 \mathrm{~h}$ (Fig. 5). The difference observed between the apparent conversion of $o$-xylene and its selectivity into $\mathrm{CO}_{2}$ suggests that part of $o$-xylene was conversed into other compounds rather than $\mathrm{CO}_{2}$ at temperatures of $245^{\circ} \mathrm{C}$ and $280{ }^{\circ} \mathrm{C}$. Thus, the catalytic oxidation for

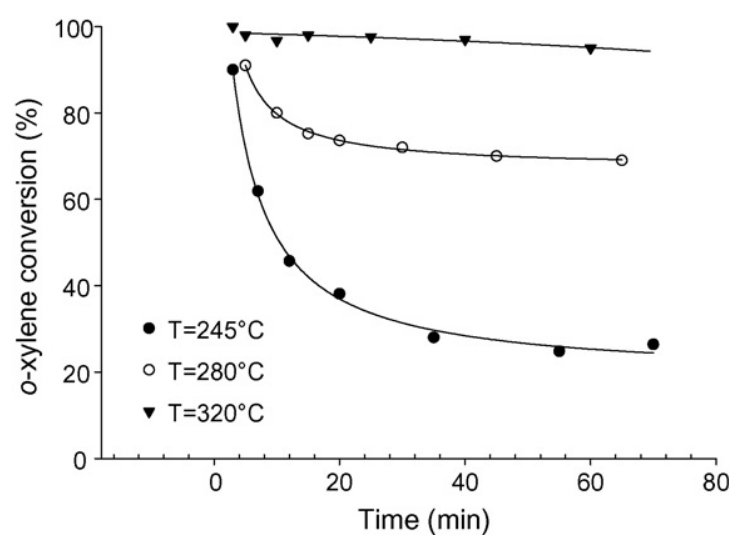

Fig. 4. Effect of reaction time on $o$-xylene conversion. Reaction conditions: $o$ xylene $461.6 \mathrm{mg} \mathrm{m}^{-3}$; air balance; total flow: $0.35 \mathrm{~m}^{3} \mathrm{~h}^{-1}$; GHSV: $11000 \mathrm{~h}^{-1}$.

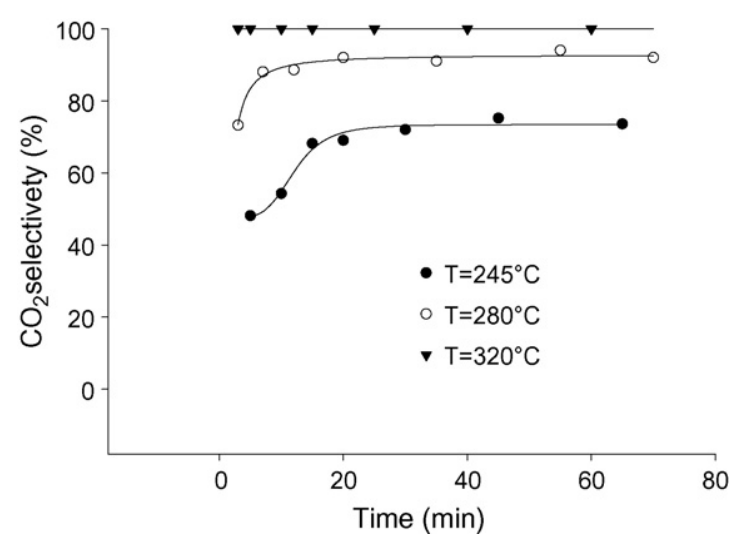

Fig. 5. Effect of reaction time on $\mathrm{CO}_{2}$ selectivity. Reaction conditions: $o$ xylene: $461.6 \mathrm{mg} \mathrm{m}^{-3}$; total flow: $0.35 \mathrm{~m}^{3} \mathrm{~h}^{-1}$; GHSV: $11000 \mathrm{~h}^{-1}$; air balance. 


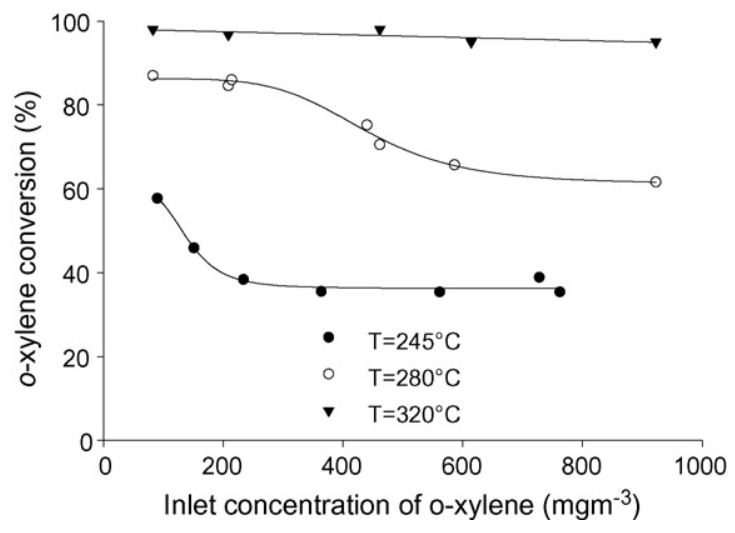

Fig. 6. Inlet concentration vs. the $o$-xylene conversion at different temperature. Reaction conditions: total flow: $0.35 \mathrm{~m}^{3} \mathrm{~h}^{-1}$ with air balance; GHSV: $11000 \mathrm{~h}^{-1}$.

treating $o$-xylene should be carried out at the temperature above $320{ }^{\circ} \mathrm{C}$.

\subsection{3. o-Xylene inlet concentration}

As the space velocity for the reaction was maintained at $11000 \mathrm{~h}^{-1}$, the inlet loads of catalytic oxidation unit changed with the inlet concentrations of $o$-xylene. Fig. 6 exhibits the changes of inlet concentration versus the $o$-xylene conversion at different temperatures, i.e. 245,280 and $320{ }^{\circ} \mathrm{C}$. At $245^{\circ} \mathrm{C}$, the removal of $o$-xylene decreased swiftly from 57 to $35.5 \%$ with the $o$-xylene inlet concentration ranging from 85 to $200 \mathrm{mg} \mathrm{m}^{-3}$. Then, the removal efficiency retained to $35.5 \%$ with the increasing of inlet concentration. Similarly, at $280{ }^{\circ} \mathrm{C}$, the removal of $o$-xylene was $87 \%$ with inlet concentrations varying from 85 to $250 \mathrm{mg} \mathrm{m}^{-3}$ and decreased from 87 to $65 \%$ as the inlet concentrations increased from 250 to $600 \mathrm{mg} \mathrm{m}^{-3}$. Further increase of the inlet concentration slowly reduced the removal efficiency to $65 \%$ and then stabilized. The removal of $o$-xylene decreased slightly with the increase of the inlet $o$ xylene concentration at higher temperature, and the removal efficiency could maintain $98 \%$ at temperature of $320{ }^{\circ} \mathrm{C}$ in this experiment. At the lower temperature, the $o$-xylene conversion was apparently more influenced by the inlet concentration.

\subsection{Characterazition of $\mathrm{Cu} / \mathrm{Al}_{2} \mathrm{O}_{3}$ in the catalytic oxidation of o-xylene}

\subsubsection{DRIFTS results}

The reaction mechanism of $o$-xylene oxidation over $\mathrm{Cu} /$ $\mathrm{Al}_{2} \mathrm{O}_{3}$ was investigated using DRIFTS. Fig. 7 demonstrates in situ DRIFTS spectra of $\mathrm{Cu} / \mathrm{Al}_{2} \mathrm{O}_{3}$ in the flow of $o$-xylene and $\mathrm{O}_{2}$ at various temperatures. The bands at 1578, 1497, 1468 and $1389 \mathrm{~cm}^{-1}$ can be assigned to the feature of $o$-xylene $[23,24]$. Accompanying with the disappearance of the feature of $o$ xylene at $150{ }^{\circ} \mathrm{C}$, new bands were observed at 1595, 1450 and $1396 \mathrm{~cm}^{-1}$. These bands can be assigned to surface acetate [25] and formate [26] species, indicating that the oxidation of $o$ xylene undergoes acetate and/or formate species on $\mathrm{Cu} / \mathrm{Al}_{2} \mathrm{O}_{3}$. The results of DRIFTS also demonstrated that the intermediate reaction species, e.g. acetate and formate species appeared on

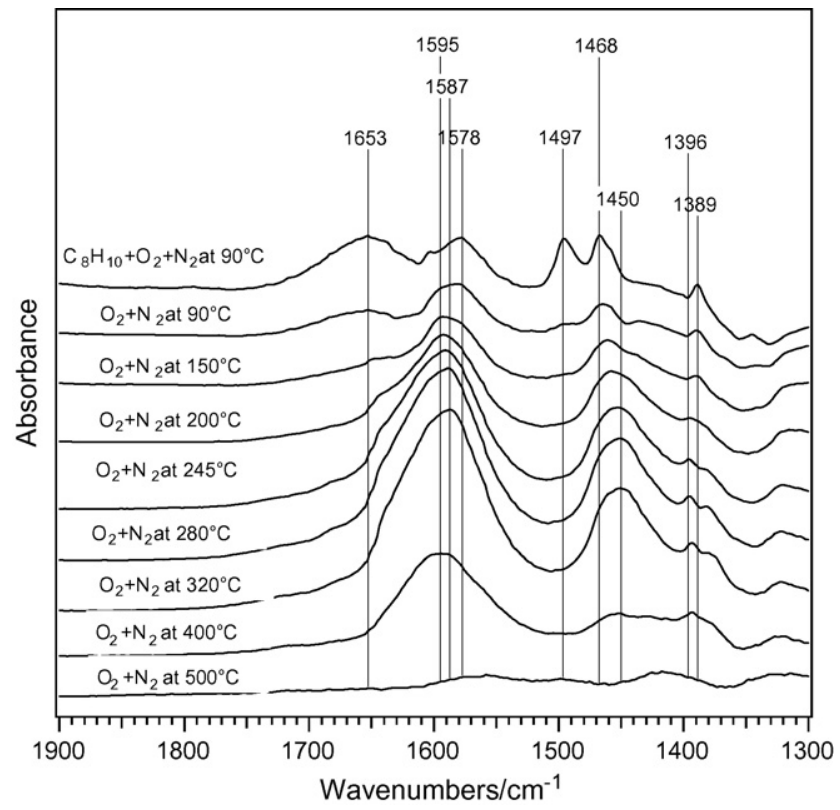

Fig. 7. DRIFTS spectra of $\mathrm{Cu} / \mathrm{Al}_{2} \mathrm{O}_{3}$ in a flow of $20 \% \mathrm{O}_{2} / \mathrm{N}_{2}$ at various temperatures after exposing catalyst to a flow of $300 \mathrm{ppm} o$-xylene $+20 \%$ $\mathrm{O}_{2} / \mathrm{N}_{2}$ at $90{ }^{\circ} \mathrm{C}$ for $60 \mathrm{~min}$

the catalyst surface accompanying with the disappearance of $o$ xylene at $150{ }^{\circ} \mathrm{C}$. The bands assigned to acetate species increased gradually from the temperature of $150-320^{\circ} \mathrm{C}$, indicating that the accumulation of acetate species on the catalyst surface occur. The accumulation of acetate species on the catalyst surface may lead to the deactivation of the catalyst. When the temperature was over $500{ }^{\circ} \mathrm{C}$, the bands assigned to acetate species may disappear completely. Catalyst should be regenerated at high temperature.

\subsubsection{Adsorption of o-xylene on $\mathrm{Cu} / \mathrm{Al}_{2} \mathrm{O}_{3}$ and regeneration of saturated $\mathrm{Cu} / \mathrm{Al}_{2} \mathrm{O}_{3}$}

Although $o$-xylene could be oxidized swiftly into $\mathrm{CO}_{2}$ and $\mathrm{H}_{2} \mathrm{O}$ at high temperature, it might not be ideal to keep the catalytic unit running all the time. To save energy and running cost, the catalytic unit can be intermittently operated according whether the effluent $o$-xylene concentration meets the emission standard. Hence, the performance of the catalytic unit treating $o$-xylene at ambient temperature must be evaluated. As shown in Fig. 8, $O$-xylene can be absorbed and accumulated on $\mathrm{Cu} /$ $\mathrm{Al}_{2} \mathrm{O}_{3}$ at ambient temperature. At $189.4 \mathrm{mg} \mathrm{m}^{-3}$ of the $o$ xylene concentration in influent and $11000 \mathrm{~h}^{-1}$ of the space velocity, the effluent concentration of $o$-xylene increased with time. After $60 \mathrm{~min}$, the effluent concentration exceeded $100 \mathrm{mg} \mathrm{m}^{-3}$ of the emission standard due to the saturation of $o$-xylene adsorption on the catalyst surface and the deactivation of catalyst.

After the $\mathrm{Cu} / \mathrm{Al}_{2} \mathrm{O}_{3}$ was deactivated during the $o$-xylene adsorption process described above, TPO of $o$-xylene was performed by heating the sample to $800{ }^{\circ} \mathrm{C}$ in a flow of $30 \mathrm{~cm}^{3} \mathrm{~min}^{-1} 20 \% \mathrm{O}_{2} / \mathrm{He}$. The TPO patterns in Fig. 9 show that the $o$-xylene started to be oxidized into $\mathrm{CO}_{2}$ at only $100{ }^{\circ} \mathrm{C}$ with a maximum peak at $400{ }^{\circ} \mathrm{C}$. In addition, trace amount of acetone $(m / z=43,58)$ was also observed, but no $o$-xylene and 


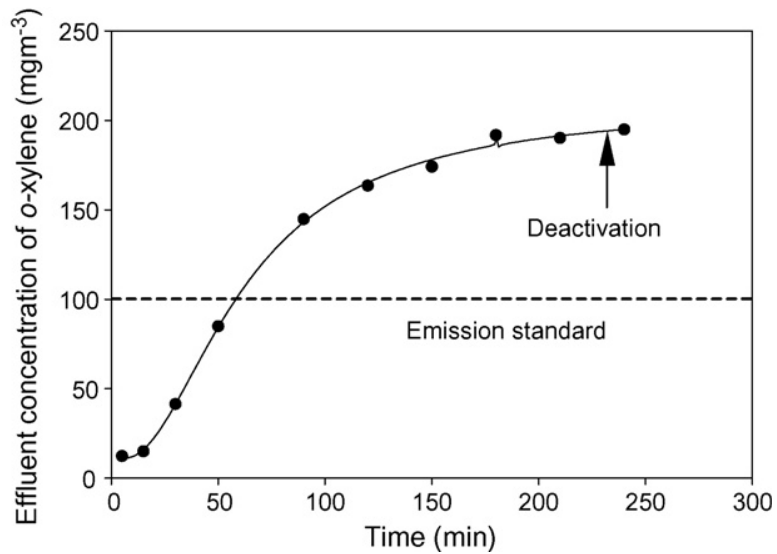

Fig. 8. Adsorption of $o$-xylene on $\mathrm{Cu} / \mathrm{Al}_{2} \mathrm{O}_{3}$. Reaction conditions: $o$-xylene: $189.4 \mathrm{mg} \mathrm{m}^{-3}$; room temperature; total flow: $0.35 \mathrm{~m}^{3} \mathrm{~h}^{-1}$; GHSV: $11000 \mathrm{~h}^{-1}$; air balance.

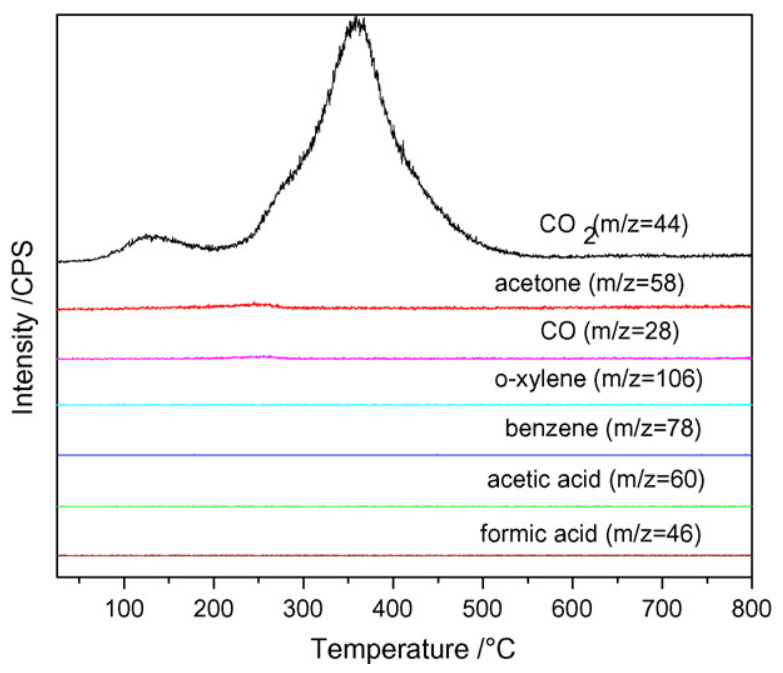

Fig. 9. TPO pattern of $o$-xylene on the deactivated $\mathrm{Cu} / \mathrm{Al}_{2} \mathrm{O}_{3}$.

other by-products were found. After TPO treatment, the regenerated $\mathrm{Cu} / \mathrm{Al}_{2} \mathrm{O}_{3}$ showed a capacity of the adsorption and oxidation of $o$-xylene similar to the fresh $\mathrm{Cu} / \mathrm{Al}_{2} \mathrm{O}_{3}$ (data not shown). These results indicate that heating the catalyst in oxidation atmosphere is an effective method in regenerating the deactivated $\mathrm{Cu} / \mathrm{Al}_{2} \mathrm{O}_{3}$ catalyst.

\section{Conclusions}

The integrated system with a biofilter and a catalytic oxidation unit can effectively oxidize $o$-xylene with high removal efficiency and elimination capacity at all tested $o$ xylene inlet concentrations. The total removal efficiency was $98 \%$. With the catalytic oxidation unit, the removal efficiency of $o$-xylene increased especially when the biofiltration unit was overloaded. The total elimination capacity was enhanced regularly with the inlet load.

The temperature of catalytic unit and the concentration of $o$ xylene in inlet gases influenced the $o$-xylene conversion. The $\mathrm{Cu} / \mathrm{Al}_{2} \mathrm{O}_{3}$ demonstrated a relatively low conversion temperature $\left(320{ }^{\circ} \mathrm{C}\right)$ with a high $\mathrm{CO}_{2}$ selectivity $(100 \%)$.

DRIFTS results indicated that the oxidation of $o$-xylene underwent acetate and/or formate species on $\mathrm{Cu} / \mathrm{Al}_{2} \mathrm{O}_{3}$. TPO results demonstrated that heating catalyst in oxidation atmosphere could be an effective method in regenerating the deactivated $\mathrm{Cu} / \mathrm{Al}_{2} \mathrm{O}_{3}$ catalyst.

\section{Acknowledgments}

Our thanks should go to Dr. YU Yun-bo and Dr. WEI Yuansong for the work of DRIFTS analysis and the manuscript revision.

This work was financially supported by the National Natural Science Foundation of China (No. 50621804 and No. 20637001).

\section{References}

[1] J.W. van Groenestijn, P.G.M. Hesselink, Biodegradation 4 (1993) 283.

[2] I.G. Jung, C.H. Park, Chemosphere 61 (2005) 451.

[3] H.H.J. Cox, R.E. Moerman, S. van Baalen, W.N.M. van Heiningen, W. Harder, Biotechnol. Bioeng. 53 (1997) 261.

[4] C. Kennes, M.C. Veiga, J. Biotechnol. 113 (2004) 305.

[5] G.A. Sorial, F.L. Smith, M.T. Suidan, A. Pandit, P. Biswas, R.C. Brenner J. Environ. Eng. 123 (6) (1997) 530.

[6] C. Lu, M.R. Lin, I. Wey, J. Chem. Technol. Biotechnol. 76 (2001) 820.

[7] S.H. Yeom, A.J. Daugulis, Biotechnol. Bioeng. 72 (2001) 156.

[8] M. Zilli, E. Palazzi, L. Sene, A. Converti, M.D. Borghi, Process Biochem. 37 (2001) 423.

[9] R. Dehghanzadeh, A. Torkian, B. Bina, H. Poormoghaddas, A. Kalantary, Chemosphere 60 (2005) 434.

[10] J.W. van Groenestijn, J.X. Liu, Atmos. Environ. 36 (2002) 5501.

[11] A. Aizpuru, L. Malhautier, J.C. Roux, J.L. Fanlo, Biotechnol. Bioeng. 83 (2003) 479.

[12] J.S. Devinny, D.S. Hodge, J. Air Waste Manage. Assoc. 45 (1995) 125.

[13] A.J. Daugulis, N.G. Boudreau, Biotechnol. Lett. 25 (2003) 1421.

[14] J.S. Devinny, M.A. Deshusses, T.S. Webster, Biofiltration for Air Pollution Control, Lewis publishers, New York, NY, 1999, Chapter 1, p. 6.

[15] M. Guisnet, P. Dege, P. Magnoux, Appl. Catal. B Environ. 20 (1999) 1.

[16] J. Tsou, L. Pinnard, P. Magnoux, J.L. Fegueiredo, M. Guisnet, Appl. Catal. B Environ. 46 (2003) 371.

[17] P. Dege, L. Pinard, P. Magnoux, M. Guisnet, Chemistry 4 (2001) 41.

[18] J.J. Li, Z. Jiang, Z.P. Hao, X.Y. Xu, Y.H. Zhuang, J. Mol. Catal. A-Chem. 225 (2005) 173.

[19] H. Yamanaka, R. Hamada, H. Nibuta, S. Nishiyama, S. Tsuruya, J. Mol. Catal. A-Chem. 178 (2002) 89.

[20] L. Becker, H. Forster, Appl. Catal. B Environ. 17 (1998) 43.

[21] L. Becker, H. Forster, Appl. Catal. A. Gen. 153 (1997) 31.

[22] H. He, C. Zhang, Y. Yu, Catal. Today 90 (2004) 191.

[23] J. Chao, Thermochim. Acta 72 (1984) 323.

[24] W.J. Taylor, J. Res. Nat. Bur. Stand 37 (1946) 95.

[25] Y. Yu, H. He, Q. Feng, J. Phys. Chem. B107 (2003) 13090.

[26] C. Zhang, X. Shi, H. Gao, H. He, J. Environ. Sci. 17 (2005) 429. 